\title{
PERSPECTIVES OF AUTONOMOUS SYSTEMS IN MILITARY APPLICATIONS
}

\section{Witold Kortyka ${ }^{\circledR}$}

War Port Command, Rondo Bitwy pod Oliwa 1 Str., 81-103 Gdynia, Poland; e-mail: w.kortyka@ron.mil.pl; ORCID ID 0000-0003-4704-3991

\begin{abstract}
In the field of communication on land and in the air, there are already functioning fully or partially autonomous devices. However, it is difficult to point to similar solutions regarding autonomous systems, especially in military applications.

The article formulates development perspectives for marine autonomous systems in military applications, taking into account achieved benefits, requirements and development restrictions. Many interesting places devoted to the security of autonomous systems, on the clear improvement of the security situation with the above-mentioned systems, equipment and machines for maintenance, management devices, autonomous systems, controls and controls, devices for carrying out operations.

The recommendations indicate the need to implement joint projects in the field of the development of autonomous marine technologies and are critical in the previous activities undertaken in this field of research.
\end{abstract}

\section{Keywords:}

autonomous technology, electromagnetic pulse (EMP), research, requirements.

Research article

(C) 2019 Witold Kortyka This is an open access article licensed under the Creative Commons Attribution-NonCommercial-NoDerivatives 4.0 license (http://creativecommons.org/licenses/by-nc-nd/4.0/) 


\section{INTRODUCTION}

The article is a summary of this year's Polish-Swedish forum on marine technology 'Autonomous technology - replacing people'. It presents the results of statements made by expert debate and focus meetings. The participants of the debates were people from the academic environment of the Gdansk University of Technology, Naval Academy, Maritime Office in Gdynia, Vinnova - the Swedish government agency, Ministry of Defence National Recession and business representatives.

These people were treated in the first stage of the research as a group of experts whose answers have a more precise character than the answers obtained in the study of documents. The group interview carried out subsequently contributed to the creation of catalogues of recommendations for individuals and institutions responsible for the development of marine autonomous systems in military applications.

\section{PURPOSES AND BACKGROUND OF RESEARCH}

The main objective of the research was to determine the development prospects of marine autonomous systems in military applications.

As part of the main objective, specific objectives have been distinguished:

1. Determining the benefits of using offshore autonomous systems.

2. Determining the requirements for the development of navigation technology, communication and port infrastructure.

3. Characteristics of adversity in the way of introducing marine autonomous systems.

In 2010, predicting the development of marine technologies would probably be futuristic considerations. In 2019, due to the significant progress in the development of sensor technologies that enable the creation of virtual reality of the marine environment and the development of algorithms and computational processes enabling the implementation of these processes in near real time, there is the possibility of conducting scientific research as an expert debate, forecasting the development of autonomous marine technologies in military applications. 
Previous research on the development of autonomous technologies and in particular unmanned aerial vehicles and autonomous cars offer a wide source of publicly available data on the abovementioned technologies. Data obtained from many sensors that collect data in the area of various technologies allow to build a multidimensional map of the environment of the object's functioning, which gives grounds for developing algorithms that enable operation of the object at various levels of automation.

Based on the historical causes of revolutionary technological changes in military solutions, it is deduced that the experience of the defeat of the US Army in Vietnam resulted in widespread acceptance of the development of innovative military technologies, which then contributed to the most important changes of war equipment since the war, i.e. the development of precision guided munitions. Since one of the main problems of the armed forces in the course of combat operations is the necessity of popular social support, it also forces the need to minimize the number of victims of armed conflicts.

This indicates that while formulating the doctrines of the use and development of armed forces, there is a need to find answers to questions. What technique should be used and how do we prepare soldiers to use this technique?

The doctrine of multidimensional operations envisages a large intensification of activities carried out in theater with the use of resources based on information systems. Intensification of activities contributes to the increase of threats related to the maneuver of elements of the grouping and fire. This requires the use of command and control systems that synchronize the operation of all components of the operation.

The analysis of the available information shows that in the field of onshore and aerial communication, there are already solutions that enable the functioning of fully or partially autonomous devices. However, it is difficult to point to similar solutions regarding marine autonomous systems, especially in military applications.

The military, as well as other bureaucratic organizations, are based on new things, especially if the change involves degradation of teams and the need to master new skills and overcome rivalry between different armed forces [10].

Especially the environment related to the navy, naval service, its ethos and heroism is particularly skeptical about the development of autonomous technologies that prevent the development of professional careers related to the service on vessels.

The above-mentioned phenomena induce scientists to undertake scientific research in order to determine the real causes of the slow and inadequate development of military autonomous marine technologies. 


\section{RESEARCH METHODOLOGY}

\section{Characteristics of the method}

Qualitative research, despite the fact that their accuracy is weakened by the inability to control interfering variables, and the relatively small size of the studied group and its unrepresentativeness, introduce a new quality for analysis. The information received is of a content nature and is extremely useful in areas for which the measurement scales are impossible to evaluate.

Qualitative research is individualized, we reach out to specific people experts, their experiences and opinions. The interactions between the participants, the clash of views and their opinions are shaped during the interview.

The test procedure is based on the analysis of the content of interviews in the form of notes, description, interpretation and presentation of results.

The selection of the expert interview research technique and the focused group interview resulted from the specificity of the research problem regarding predicting the development prospects of marine autonomous systems in military applications. The use of group interviews allows us to get answers to questions, which affect the development prospects of marine autonomous systems in military applications.

\section{Criteria for the evaluation of results}

In order to ensure the triangulation of research methods and to obtain reliable information, a combination of knowledge verification tests was used, i.e. an expert debate with a technique enabling the analysis of interacting, i.e. focus studies. The results of the research obtained using the desk research method as well as the conclusions from the expert debate were discussed in the next day during the focused interview.

Time constraints and the specificity of the research problem consisting in predicting development, in addition to expert discussion, as one of the methods used in the prediction research also forced the use of focused group interviews. The purpose of research using these techniques is to create forecasts formulated and based on the opinions of specialists in a given field of science.

The statements of individual respondents during the interviews were analyzed. When interpreting them, the appropriate categorization key was used. 


\section{RESULTS OF EXPERT RESEARCH AND FOCUS TESTS}

First, an expert interview was conducted, followed by a group interview with a deliberate sample selection among people with expert knowledge, i.e. experience and competence in relevant science disciplines. The first group consisted of fourteen people, the second group consisted of six people. The respondents were experts from research centers and institutions mentioned in the introduction.

Tab. 1. List of conclusions from expert and focus studies

\begin{tabular}{|c|c|c|}
\hline \multirow{2}{*}{$\begin{array}{c}\begin{array}{c}\text { Expert } \\
\text { interview }\end{array} \\
\text { Problem } \\
\end{array}$} & \multicolumn{2}{|r|}{ FDI } \\
\hline & The source of the problem & Suggestions for solving the problem \\
\hline \multicolumn{3}{|c|}{ What are the benefits of the use of offshore autonomous systems in military applications? } \\
\hline $\begin{array}{l}\text { Improving } \\
\text { security }\end{array}$ & $\begin{array}{l}\text { The vast majority of accidents } \\
\text { in the marine environment were } \\
\text { caused by human error related } \\
\text { to habits, routine and fatigue. }\end{array}$ & $\begin{array}{l}\text { Automation of unit control processes and } \\
\text { traffic control in the area of activities will } \\
\text { contribute to a significant decrease in } \\
\text { the number of accidents. Continuous } \\
\text { maintenance of ground control elements } \\
\text { with a staffing is predicted. However, } \\
\text { the possibility of frequent replacement of } \\
\text { the staff will increase the comfort of work } \\
\text { and will eliminate the excessive fatigue } \\
\text { of crews. Working in a safe terrestrial } \\
\text { environment will also reduce the stress } \\
\text { caused by the effects of the opponent's } \\
\text { impact and adverse weather conditions } \\
\text { during offshore activities. }\end{array}$ \\
\hline $\begin{array}{l}\text { Operating } \\
\text { costs }\end{array}$ & $\begin{array}{l}\text { Maintenance of the vessel's crew } \\
\text { together with the watch-keeping } \\
\text { system generates significant labor } \\
\text { costs. }\end{array}$ & $\begin{array}{l}\text { In order to reduce costs, the composition of } \\
\text { the crew is reduced and the operating } \\
\text { processes of the unit are automated. } \\
\text { However, this does not affect the possibility } \\
\text { of eliminating elements of the vessel's } \\
\text { equipment used to provide living conditions, } \\
\text { even for the limited number of crews. } \\
\text { The complete elimination of staffing will } \\
\text { not only reduce the cost of maintaining } \\
\text { systems ensuring the existence of the crew, } \\
\text { but will allow them to be eliminated at } \\
\text { the design and construction stage of the } \\
\text { unit, limiting the construction of the unit } \\
\text { only to the cargo space and control, } \\
\text { communication and control systems. }\end{array}$ \\
\hline $\begin{array}{l}\text { Resistance } \\
\text { to weather } \\
\text { conditions }\end{array}$ & $\begin{array}{l}\text { Weather conditions have a key } \\
\text { influence on the selection of the } \\
\text { cruise route. Due to the health } \\
\text { restrictions of the crew, the choice } \\
\text { of the route, taking into account } \\
\text { weather conditions, is often not } \\
\text { optimal. }\end{array}$ & $\begin{array}{l}\text { The elimination of personal staffing will } \\
\text { allow more effective route planning, taking } \\
\text { into account only the immunity of the vessel } \\
\text { to weather conditions. }\end{array}$ \\
\hline
\end{tabular}




\begin{tabular}{|c|c|c|}
\hline $\begin{array}{c}\text { Expert } \\
\text { interview }\end{array}$ & \multicolumn{2}{|r|}{ FDI } \\
\hline Problem & The source of the problem & Suggestions for solving the problem \\
\hline $\begin{array}{l}\text { Personal } \\
\text { security }\end{array}$ & $\begin{array}{l}\text { Exploitation of units in hazardous } \\
\text { conditions carries the risk of loss } \\
\text { and injury among crews of vessels. } \\
\text { Existing threats are the impact } \\
\text { of the opponent, piracy attacks, } \\
\text { environmental contamination, } \\
\text { weather conditions, fires, sinking } \\
\text { of units, epidemics and others. }\end{array}$ & $\begin{array}{l}\text { The elimination of crews from vessels will } \\
\text { significantly increase the safety of personnel } \\
\text { at sea, despite the need to maintain servicing } \\
\text { crews ready for action. }\end{array}$ \\
\hline \multicolumn{3}{|c|}{$\begin{array}{l}\text { What are the requirements for the development of navigation, communication and port infrastructure } \\
\text { in the aspect of introducing marine autonomous systems in military applications? }\end{array}$} \\
\hline $\begin{array}{l}\text { Communication } \\
\text { technologies }\end{array}$ & $\begin{array}{l}\text { As part of commercial solutions, } \\
\text { it is possible to use existing and } \\
\text { developed navigation systems, } \\
\text { satellite communications and } \\
\text { terrestrial telecommunications } \\
\text { infrastructure. } \\
\text { The lack of developed satellite } \\
\text { navigation and communications } \\
\text { systems in the military solutions } \\
\text { of countries with limited military } \\
\text { capabilities prevents the introduction } \\
\text { of marine autonomous systems in } \\
\text { these applications to operations in } \\
\text { areas remote from the developed } \\
\text { terrestrial military infrastructure. } \\
\text { Also existing communication } \\
\text { technologies in the field of the } \\
\text { underwater environment make it } \\
\text { impossible to transmit broadband } \\
\text { data even over short distances. }\end{array}$ & $\begin{array}{l}\text { There is a need to develop military } \\
\text { technologies enabling broadband data } \\
\text { transmission over long distances, enabling } \\
\text { operation in remote areas, especially for } \\
\text { underwater units. }\end{array}$ \\
\hline $\begin{array}{l}\text { Situational } \\
\text { awareness }\end{array}$ & $\begin{array}{l}\text { Lack of direct contact with the } \\
\text { watercraft and sensations from } \\
\text { the surrounding marine environment } \\
\text { will make it impossible to gain full } \\
\text { situational awareness for the opera- } \\
\text { tors of the control center. Staying } \\
\text { on the unit with full insight into } \\
\text { the indication of cruise parameters } \\
\text { and human sensory experiences } \\
\text { allows you to make quick decisions } \\
\text { also in crisis situations. }\end{array}$ & $\begin{array}{l}\text { There is a need to develop navigation } \\
\text { technologies, control and unit maintenance } \\
\text { even in extreme conditions, which requires } \\
\text { the use of a huge number of sensors and } \\
\text { algorithms capable of interacting in a short } \\
\text { time in extreme situations. And also the } \\
\text { necessity of using technologies enabling } \\
\text { direct control of the unit, bypassing } \\
\text { autonomous systems and indirect control, } \\
\text { consisting in updating the programs } \\
\text { controlling the unit. }\end{array}$ \\
\hline $\begin{array}{l}\text { Energy } \\
\text { sources }\end{array}$ & $\begin{array}{l}\text { Continued use of liquid fuels for the } \\
\text { supply of vessels limits the possibility } \\
\text { of full use of autonomous technolo- } \\
\text { gies. The necessity of continuous } \\
\text { servicing of combustion drive units } \\
\text { as well as cyclical topping up of fuel } \\
\text { and other operating fluids results } \\
\text { in limiting the range and lifetime } \\
\text { of vessels. }\end{array}$ & $\begin{array}{l}\text { This results in the need to develop new } \\
\text { propulsion technologies using energy from } \\
\text { other sources. }\end{array}$ \\
\hline
\end{tabular}




\begin{tabular}{|c|c|c|}
\hline $\begin{array}{c}\text { Expert } \\
\text { interview }\end{array}$ & \multicolumn{2}{|r|}{ FDI } \\
\hline Problem & The source of the problem & Suggestions for solving the problem \\
\hline $\begin{array}{l}\text { Electronic } \\
\text { warfare }\end{array}$ & $\begin{array}{l}\text { The introduction of marine autono- } \\
\text { mous systems will involve the need } \\
\text { to ensure the unit's operation in } \\
\text { the conditions of electromagnetic } \\
\text { interference organized by the } \\
\text { opponent or occurring naturally. } \\
\text { Also, ensuring resistance to the occur- } \\
\text { rence of a strong electromagnetic } \\
\text { pulse - electromagnetic pulse } \\
\text { (EMP) capable of damaging sensitive } \\
\text { elements of the electronic equipment } \\
\text { of the unit seems to be crucial } \\
\text { already at the stage of designing } \\
\text { the construction of the unit. } \\
\text { The use of wireless control and } \\
\text { control systems will allow the use } \\
\text { of cyber-attacks to take control of } \\
\text { the unit. }\end{array}$ & $\begin{array}{l}\text { There is, therefore, a need to ensure effective } \\
\text { immunity of systems to interference and, in } \\
\text { the event of their occurrence, mechanisms } \\
\text { enabling the unit to leave the disturbance } \\
\text { zone and re-establish connection with the } \\
\text { control center. } \\
\text { There are solutions that ensure effective } \\
\text { defense of electronic circuits against EMP. } \\
\text { Therefore, the introduction of cyber security } \\
\text { mechanisms, i.e. direct physical link protection, } \\
\text { cryptography using interference-proof } \\
\text { communication systems, also becomes } \\
\text { a priority. }\end{array}$ \\
\hline $\begin{array}{l}\text { Defense and } \\
\text { Identification } \\
\text { Friend or Foe } \\
\text { (IFF) }\end{array}$ & $\begin{array}{l}\text { Watercraft equipped with autono- } \\
\text { mous systems must have defense } \\
\text { against destruction or unauthorized } \\
\text { access and takeover of control. } \\
\text { The autonomous system of defense } \\
\text { against the takeover of the unit as } \\
\text { well as the anti-aircraft systems } \\
\text { must be characterized by a special } \\
\text { credibility in the identification of } \\
\text { the IFF. } \\
\text { They must also provide access to } \\
\text { service crews. }\end{array}$ & $\begin{array}{l}\text { The solutions currently used in the armed } \\
\text { forces provide effective IFF identification. }\end{array}$ \\
\hline $\begin{array}{l}\text { Port } \\
\text { infrastructure }\end{array}$ & $\begin{array}{l}\text { The use of autonomous systems in } \\
\text { trans-oceanic flights is not contro- } \\
\text { versial and seems easy to implement, } \\
\text { while maneuvering in areas with } \\
\text { high intensity of navigation, in } \\
\text { straits or ports is associated with } \\
\text { collision risk. }\end{array}$ & $\begin{array}{l}\text { This results in the need to use systems of } \\
\text { interoperability between autonomous units } \\
\text { (AUV), UAV (unmanned air vehicle), UAV } \\
\text { (unmanned vehicle vehicle) and UUV } \\
\text { (unmanned underwater vehicle), between } \\
\text { autonomous units and personnel, and } \\
\text { between autonomous units and port infra- } \\
\text { structure to organize a safe entry/exit } \\
\text { to and from the port and mooring of } \\
\text { an autonomous unit. }\end{array}$ \\
\hline \multicolumn{3}{|c|}{ What obstacles stand in the way of introducing marine autonomous systems in military solutions? } \\
\hline $\begin{array}{l}\text { Legal } \\
\text { regulations }\end{array}$ & $\begin{array}{l}\text { The legal regulations currently in } \\
\text { force in international maritime safety } \\
\text { conventions make it impossible to } \\
\text { use fully autonomous vessels. } \\
\text { Also, the lack of standardizing } \\
\text { international institutions in the area } \\
\text { of development of autonomous } \\
\text { systems results in the development } \\
\text { of technologies based solely on } \\
\text { proprietary solutions of individual } \\
\text { implementation centers. }\end{array}$ & $\begin{array}{l}\text { One should expect the creation of common } \\
\text { international standards after the period of } \\
\text { commercial exploitation of technologies in } \\
\text { the field of commercial solutions. Military } \\
\text { solutions will remain the domain of countries } \\
\text { that create or possibly export technologies. }\end{array}$ \\
\hline
\end{tabular}




\begin{tabular}{|c|c|c|}
\hline \multirow{2}{*}{\begin{tabular}{|c|}
$\begin{array}{c}\text { Expert } \\
\text { interview }\end{array}$ \\
Problem \\
\end{tabular}} & \multicolumn{2}{|r|}{ FDI } \\
\hline & The source of the problem & Suggestions for solving the problem \\
\hline $\begin{array}{l}\text { Ethical } \\
\text { problems }\end{array}$ & $\begin{array}{l}\text { In extreme situations, where there } \\
\text { is a need to make key decisions in } \\
\text { the aspect of security, the final } \\
\text { decision always belongs to a man } \\
\text { who is based on legal norms, } \\
\text { procedures and morality. } \\
\text { The elimination of a man as a decision } \\
\text { element involves the necessity of } \\
\text { introducing selection algorithms at } \\
\text { the design stage of units. The dilemma } \\
\text { of choice, whose safety is more } \\
\text { important, already at the design } \\
\text { stage, seems unacceptable from } \\
\text { the ethical point of view. } \\
\text { A long-standing ethical problem } \\
\text { appears, so-called 'trolley problem' } \\
\text { [8, 9] impossible to solve from } \\
\text { an ethical point of view. However, } \\
\text { it is necessary to consider it during } \\
\text { projecting algorithms the operation } \\
\text { of autonomous systems. }\end{array}$ & Not found \\
\hline $\begin{array}{l}\text { Doctrinal } \\
\text { documents }\end{array}$ & $\begin{array}{l}\text { The lack of doctrinal documents } \\
\text { defining the directions of development } \\
\text { of marine autonomous systems } \\
\text { affects the very slow pace of } \\
\text { implementation of technologies } \\
\text { used in autonomous units in military } \\
\text { solutions of European countries. } \\
\text { Available sources indicate that } \\
\text { these technologies are successfully } \\
\text { developed in China and the USA. }\end{array}$ & $\begin{array}{l}\text { The introduction of modernization programs, } \\
\text { including marine autonomous systems, will } \\
\text { enable the direction of scientific research. }\end{array}$ \\
\hline $\begin{array}{l}\text { Research on } \\
\text { oceanography, } \\
\text { geography and } \\
\text { the marine } \\
\text { environment }\end{array}$ & $\begin{array}{l}\text { The introduction of autonomous } \\
\text { systems in both submersible and } \\
\text { submersible vessels requires } \\
\text { continuous updating of data on } \\
\text { oceanography, geography and } \\
\text { the marine environment. } \\
\text { Especially in Swedish territorial } \\
\text { waters with irregular coastline and } \\
\text { rocky bottom access to precise } \\
\text { oceanographic data is a key factor. }\end{array}$ & $\begin{array}{l}\text { The variability of the marine environment, } \\
\text { resulting from natural processes occurring } \\
\text { there, requires continuous updating of data } \\
\text { entered into navigation systems, especially } \\
\text { in underwater vessels. And thus, maintaining } \\
\text { their own research facilities and the possibility } \\
\text { of using data obtained in the international } \\
\text { environment. }\end{array}$ \\
\hline
\end{tabular}

\section{CONCLUSIONS AND RECOMMENDATIONS}

The analysis of the information collected data presented in tab. 1 allows us to determine the effectiveness of the research techniques used to achieve the purpose of the study. Problems arising during the expert interview, referring to the research 
questions, were then developed during the group in-depth interview. Which allowed us to formulate prospects for the development of marine autonomous systems in military applications taking into account the benefits, requirements and limitations of development.

Particular attention has been paid to the problem of ensuring the safety of marine autonomous systems, pointing to a clear improvement in the security situation using the abovementioned systems.

Another problem raised during the research was the necessity of parallel development of technologies securing the functioning of marine autonomous systems. Significant delimitations resulting from uneven development of maritime autonomous systems technologies and communication systems, port infrastructure and their resistance to counteracting were pointed out. There is a need for further work enabling standardization, system integration and increasing communication capabilities, especially in military applications.

In terms of determining the adversity in the implementation of offshore autonomous systems, there was a lack of international legal regulations enabling the implementation of these technologies and doctrinal documents defining the development directions of maritime autonomous systems at the state level. Introduction of the above regulations would allow us to focus research into the development of these systems.

The ethical problem indicated during the expert interview was then developed during the focus meeting. However, no solution was presented to solve this problem. These problems undertaken in popular science literature remain unanswered. Although reality is increasingly asking open questions about ethical problems about autonomous systems. The currently discussed UBER semi-automatic vehicle accident is an example of how a single incident can slow down the development of autonomous technologies. Ethical issues remain unresolved. As a result of expert research, it is also difficult to determine the perspectives for the development of autonomous technologies in the aspect of moral dilemmas.

In summary, it should be stated that the development process of offshore autonomous systems, due to the significant advantage of benefits over obstacles, will be continued at an intense pace. The development of these technologies is much faster in countries with significant economic potential, navigation technologies and communication. It is focused on the development of maritime economies like China and the USA.

In countries with lower potential, research is being carried out. However, their use in the first stage will be limited only to activities within these countries. 
The development of marine autonomous systems in military applications will likely encounter organizational, technological and mental obstacles. This will likely be the cause of significant delays in the implementation of these technologies as compared to commercial applications.

Activities undertaken so far to develop autonomous marine technologies raise in the field of international civil-military projects are insufficient. The most important recommendations in this area are listed below:

1. Activities promoting the development of autonomous marine technologies in research centers should be considered disappointing, its should be intensified by promoting the idea of implementing the above-mentioned technology.

2. Promoting activities to be carried out especially in the environment of maritime safety authorities, which will affect decisions regarding the directions of modernization of the state's maritime security systems and the departure from the classic non-autonomous solutions. Despite the occurrence of skepticism and avoiding controversial decisions related to a strong military lobby promoting classic solutions (e.g. purchase of F-35 aircraft).

3. Design work should be carried out in the field of autonomous marine technologies in military applications, which will allow to significantly reduce the construction and operation costs of vessels, and eliminate the safety hazards for floating crews, which will be a more advantageous alternative to classic solutions.

4. Further research into the development of autonomous marine technologies should be carried out using the intensive development of unmanned aircraft technology (drones) and communication technologies (5G).

5. Conduct further research on threats related to maritime piracy, i.e. taking over vessels and kidnapping crews for ransom and costs of organizing physical protection of vessels. The introduction of autonomous marine technologies will avoid these kinds of threats due to the lack of crews and physical control elements of vessels. This solution will significantly reduce the operating costs of vessels.

6. Design work enabling the development of autonomous marine technologies should be closely related to the development of port infrastructure enabling the acquisition of a vessel at the entrance to the port (ILS - instrument landing system, radio navigation system, assisting in aviation).

7. The variety of problems related to the introduction of autonomous technologies requires the organization of cooperation between scientific, industrial and state institutions in many areas, including in the area of safety of crews, vessels and sea traffic. 
8. There is a necessity to establish an initiative to create a project combining scientific, industrial, design centers of vessels and other, in order to conduct research to solve technological, economic, social and legal problems enabling the further development of military autonomous marine technologies.

\section{REFERENCES}

[1] Blanding H. C., Automation of Ships and the Human Factor, Ship Technology and Research Symposium of The Society of Naval Architects and Marine Engineers, Philadelphia 1987.

[2] Hallevy G., When robots kill, Northeastern University Press, 2013.

[3] Lang D., Update on the Worldwide Supplyand Demand for Seafarers, Report from the Baltic and International Maritime Council (BIMCO) and the International Shipping Federation (ISF), 2010.

[4] Maj A., Wstępny raport po śmiertelnym wypadku Ubera - winne oprogramowanie [Preliminary report after Uber's fatal accident - guilty software], Autoblog, [online], https://spidersweb.pl/autoblog/wsteny-raport-po-smiertelnym-wypadku-ubera-winneoprogramowanie [access 20.08.2019].

[5] Man Y., Porathe T., Prison J., Situation Awareness in Remote Control Centers for Unmanned Ships, Human Factor in Ship Design and Operation, London 2014.

[6] Rothblum A. M., Human Error and Marine Safety, U.S. Coast Guard and Research and Development Center, 2002.

[7] Sanquist T. F., Human Factors in Maritime Applications: A New Opportunity for Multi-Modal Transportation Research, Proceedings of the Human Factors 36th Annual Meeting, 1992.

[8] Thomson J. J., Killing, letting die, and the Trolley Problem, 'The Monist', 1976, 59, pp. 204-217.

[9] Thomson, J. J., The Trolley Problem, 'The Yale Law Journal', 1985, 94(6), pp. 1395-1415.

[10] Toffler A. H., War and Anti-War: Making Sense of Today's Global Chaos, New York 1995.

\section{PERSPEKTYWY SYSTEMÓW AUTONOMICZNYCH W ZASTOSOWANIACH WOJSKOWYCH}

\section{STRESZCZENIE}

W dziedzinie komunikacji na lądzie i w powietrzu stosuje się rozwiązania umożliwiające funkcjonowanie urządzeń w pełni lub częściowo autonomicznych. Trudno jednak wskazać na podobne wyniki w odniesieniu do morskich systemów autonomicznych, szczególnie w zastosowaniach militarnych.

4 (219) 2019 
W artykule sformułowano perspektywy rozwoju morskich systemów autonomicznych w aplikacjach militarnych z uwzględnieniem osiąganych korzyści, wymagań i ograniczeń rozwoju. Szczególnie dużo uwagi poświęcono problemowi zapewnienia bezpieczeństwa morskich systemów autonomicznych. Wskazano na wyraźną poprawę stanu bezpieczeństwa przy ich zastosowaniu, konieczność równoległego rozwoju technologii zabezpieczających funkcjonowanie morskich systemów autonomicznych oraz na brak międzynarodowych uregulowań prawnych umożliwiających implementację tych technologii.

Sformułowany w artykule katalog rekomendacji wskazuje na konieczność realizacji wspólnych międzynarodowych projektów cywilno-wojskowych w zakresie rozwoju autonomicznych technologii morskich i w sposób krytyczny charakteryzuje dotychczasowe działania podejmowane w tym obszarze.

\section{Słowa kluczowe:}

systemy autonomiczne, badania, wymagania.

Article history

Received: 22.03.2019

Reviewed: 28.06.2019

Revised: $\quad 20.11 .2019$

Accepted: 17.12.2019 